\title{
Production and assay of cellulolytic enzyme activity of Enterobacter cloacae WPL 214 isolated from bovine rumen fluid waste of Surabaya abbatoir, Indonesia
}

\author{
W. P. Lokapirnasari ${ }^{1}$, D. S. Nazar $^{1}$, T. Nurhajati ${ }^{1}$, K. Supranianondo ${ }^{1}$ and A. B. Yulianto ${ }^{2}$
}

1. Department of Animal Husbandry, Faculty of Veterinary Medicine, Airlangga University, Jl. Mulyorejo, Campus C Unair, Surabaya, Indonesia; 2. Faculty of Veterinary Medicine, Wijaya Kusuma Surabaya University, Jl. Dukuh Kupang Barat $\mathrm{XVI} / 1$ Surabaya, Indonesia.

Corresponding author: W. P. Lokapirnasari, e-mail:wp_lokapirnasari@yahoo.com, DSN: dady_sn_drh@yahoo.com, TN: tri_nurhajati@yahoo.com, KS: koesnotosp@yahoo.com, ABY: bernyjuliantomiroen@gmail.com

Received: 12-11-2014, Revised: 27-01-2015, Accepted: 05-02-2015, Published online: 21-03-2015

doi: 10.14202/vetworld.2015.367-371. How to cite this article: Lokapirnasari WP, Nazar DS, Nurhajati T, Supranianondo K, Yulianto AB (2015) Production and assay of cellulolytic enzyme activity of Enterobacter cloacae WPL 214 isolated from bovine rumen fluid waste of Surabaya abbatoir, Indonesia, Veterinary World 8(3): 367-371.

\begin{abstract}
Aim: This study aims to produce and assay cellulolytic enzyme activity (endo- $(1,4)-\beta$ - $D$-glucanase, exo- $(1,4)-\beta$ - $D$ glucanase, and $\beta$-glucosidase, at optimum temperature and optimum $\mathrm{pH}$ ) of Enterobacter cloacae WPL 214 isolated from bovine rumen fluid waste of Surabaya Abbatoir, Indonesia.

Materials and Methods: To produce enzyme from a single colony of E. cloacae WPL $214,98 \times 10^{10} \mathrm{CFU} / \mathrm{ml}$ of isolates was put into $20 \mathrm{ml}$ of liquid medium and incubated in a shaker incubator for $16 \mathrm{~h}$ at $35^{\circ} \mathrm{C}$ in accordance with growth time and optimum temperature of E. cloacae WPL 214. Further on, culture was centrifuged at $6000 \mathrm{rpm}$ at $4^{\circ} \mathrm{C}$ for $15 \mathrm{~min}$. Pellet was discarded while supernatant containing cellulose enzyme activity was withdrawn to assay endo- $(1,4)-\beta-D$-glucanase, exo-(1,4)- $\beta$-D-glucanase, and $\beta$-glucosidase.
\end{abstract}

Results: Cellulase enzyme of E. cloacae WPL 214 isolates had endoglucanase activity of $0.09 \mathrm{U} / \mathrm{ml}$, exoglucanase of $0.13 \mathrm{U} / \mathrm{ml}$, and cellobiase of $0.10 \mathrm{U} / \mathrm{ml}$ at optimum temperature $35^{\circ} \mathrm{C}$ and optimum $\mathrm{pH} 5$.

Conclusion: E. cloacae WPL 214 isolated from bovine rumen fluid waste produced cellulose enzyme with activity as cellulolytic enzyme of endo-(1,4)- $\beta$-D-glucanase, exo-(1,4)- $\beta$-D-glucanase and $\beta$-glucosidase.

Keywords: endo-(1,4)- $\beta$-D-glucanase, exo-(1,4)- $\beta$-D-glucanase, $\beta$-glucosidase., Enterobacter cloacae WPL 214.

\section{Introduction}

Rumen is an excellent environment for microbial growth consisting of bacteria, fungi and protozoa which are widely known to play important role in the fermentation process of ruminant cattle feed [1]. Cellulase is an enzyme produced by cellulolytic microbes capable of hydrolizing $\beta-1,4$ glycoside bond in cellulose, a polysaccharide structure often found in plants [2].

Cellulose degradation by cellulolytic bacteria is a product of synergy in a group of cellulase enzymes. Cellulase enzyme system consists of three groups of hydrolytic enzymes, i.e. (1) endo- $(1,4)-\beta$-D-glucanase (endoglucanases), (2) exo- $(1,4)-\beta$-D-glucanase (exoglucanases), and (3) $\beta$-glucosidase [3].

Endo-(1,4)- $\beta$-D-glucanase enzyme hydrolyzes $\beta$ bonds randomly in a morphous regions of cellulose fibers [4], generates oligosaccharides of different lengths, and can form a new chainend [5]. Exo-(1,4)$\beta$-D-glucanase enzyme works towards reducing and non-reducing end of polysaccharide chains, especially on crystalline cellulose region, and liberates glucose as the main product resulted by $\beta$-glucosidase

Copyright: The authors. This article is an open access article licensed under the terms of the Creative Commons Attributin License (http:// creative commons.org/licenses/by/2.0) which permits unrestricted use, distribution and reproduction in any medium, provided the work is properly cited. enzyme. Hydrolysis of crystal line cellulose part can only be done efficiently by exoglucanase enzyme. The synergy between endoglucanases and exoglucanases enzymes produces cellobiose molecules. Cellulose hydrolysis effectively requires an enzyme ( $\beta$-glucosidase) that breaks down cellobiose into two molecules of glucose $[5,6]$.

The cost of using commercial cellulose enzymes is still expensive, making it less economical when applied in livestock industry in relation to provision and improvement of feed quality. Thus, other cellulolytic microbes capable of degrading fibrous feed stuffs need developing. Biodegradation by Enterobacter cloacae WPL 214 rumen cellulolytic bacteria is expected to be able to be used as degrading source material for fibrous feed stuffs at a cheaper price compared to commercial cellulose enzymes.

\section{Materials and Methods}

\section{Materials}

Cellulolytic enzyme activity

Media used in this study were Luria Bertani medium (1 g trypton, $0.5 \mathrm{~g}$ bacto yeast extract and $1 \mathrm{~g} \mathrm{NaCl})$; dinitrosalicylic acid $\left(\mathrm{C}_{4} \mathrm{H}_{4} \mathrm{KNaO}_{6} \cdot 4 \mathrm{H}_{2} \mathrm{O}\right)$, (Merck); Natriumhydroxide $(\mathrm{NaOH})$, (Merck); 3,5 - dinitrosalicylic acid, (Sigma); Sodium Sulfite 
$\left(\mathrm{Na}_{2} \mathrm{SO}_{3}\right)$, citric acid, $\mathrm{Na}_{2} \mathrm{HPO}_{4} .7 \mathrm{H}_{2} \mathrm{O}, \mathrm{NaHPO}_{4}$, p-nitrophenyl cellobioside (PNPC), carboximethyl cellulose (CMC), p-nitrophenyl- $\beta$-D-glukopiranoside (pNPG), p-nitrophenol.

\section{Methods}

Measurement of E. cloacae WPL 214 growth curve

$10 \mathrm{ml}$ of cultured E. cloacae WPL 214 isolates was taken and transferred to $100 \mathrm{ml}$ growth medium in Erlenmeyer flask. Culture suspensions were incubated in a shaker incubator $\left(37^{\circ} \mathrm{C}, 120 \mathrm{rpm}\right)$. Optical density (OD) was measured at $\lambda 600 \mathrm{~nm}$ by taking as much as $1 \mathrm{ml}$ sampling with interval of $2 \mathrm{~h}$ for $30 \mathrm{~h}$ (h $0 ; 2 ; 4$; $6 ; 10 ; 12 ; 14 ; 16 ; 18 ; 20 ; 22 ; 24 ; 26 ; 28 ; 30)$. The first sampling was done at 0 th $h$ and continued until OD values showed a clear decline. OD was measured with $U V$-vis spectrophotometer at $\lambda 600 \mathrm{~nm}$. Growth curve was obtained from the result of absorbance measurement on the time.

\section{Measurement of E. cloacae WPL 214 optimum temperature and $\mathrm{pH}$}

$1 \mathrm{ml}$ of cultured cellulolytic bacteria isolates of E. cloacae WPL 214 was taken and transferred into $10 \mathrm{ml}$ Luria Bertani growth medium in erlenmeyer flask. Culture suspensions were incubated for $24 \mathrm{~h}$ in a shaker incubator at $30^{\circ} \mathrm{C}, 35^{\circ} \mathrm{C}, 40^{\circ} \mathrm{C}$ and $\mathrm{pH} 4,5$, $6,7,8$ with shaking at $120 \mathrm{rpm}$. OD measurement was conductedby taking $1 \mathrm{ml}$ sampling. OD was measured using UV-Vis spectrophotometer at $\lambda 600 \mathrm{~nm}$.

\section{Cellulase enzyme production of E. cloacae WPL 214}

Enzyme activity assay was conducted on enzyme produced from optimum growth time and temperature in the following way: Single colony of E. cloacae of $98 \times 10^{10} \mathrm{CFU} / \mathrm{mlwas}$ put into $20 \mathrm{ml}$ of liquid medium and incubated in a shaker incubator for $16 \mathrm{~h}$ at $35^{\circ} \mathrm{C}$. Afterwards, culturewas centrifuged at $6000 \mathrm{rpm}$ at $4^{\circ} \mathrm{C}$ for $15 \mathrm{~min}$. Pellet was discarded while supernatant containing cellulase enzyme was taken to assay endo-(1,4)- $\beta$-D-glucanase, exo-(1,4)- $\beta$-D-glucanase, and $\beta$-glucosidase enzyme activity.

\section{Assay of endo-(1,4)- $\beta$-D-glucanase E. cloacae WPL 214 activity}

Assay of endo-(1,4)- $\beta$-D-glucanase activity was conducted using 3.5-dinitrosalisilat acid (DNS) method by using CMC as a specific substrate. Endo$(1,4)-\beta$ - $D$-glucanase activity was assayed by mixing $100 \mathrm{ml}$ enzyme with $100 \mathrm{ml}$ substrate $(1 \% \mathrm{CMC}$ in $0.1 \mathrm{M}$ citratephosphate bufferat $\mathrm{pH} 7$ ) and incubating it in a water bath at $50^{\circ} \mathrm{C}$ for $30 \mathrm{~min}$. Enzyme activity of an amount of formed reducing sugars was measured using DNS method by adding $600 \mu 1$ DNS into tube and placing it in a boiling water bath for $15 \mathrm{~min}$ together with control (containing $100 \mu$ l enzyme mixed with $600 \mu 1$ and $100 \mu 1$ substrate, without incubation) and finally cooling it in ice water for $20 \mathrm{~min}$. Total volume of enzyme activity assay in this study was $800 \mu \mathrm{l}$. Absorbance measurement was afterward conducted using cuvettes. Absorbance was read using spectrophotometer at $\lambda 550 \mathrm{~nm}$. One unit of enzyme activity was defined as the amount of enzyme required to form $1 \mathrm{mmol}$ of product per unit time for each $\mathrm{ml}$ of enzyme $[7,8]$.

\section{Assay of exo-(1,4)- $\beta-D-g$ lucanase $E$. cloacae WPL 214 activity}

To measure exo-(1,4)- $\beta$-D-glucanase activity, $100 \mu \mathrm{l}$ enzyme mixed with $900 \mu \mathrm{l}$ pNPC $(1 \mathrm{mMol}$ $p$ NPC in $10 \mathrm{ml}$ of citrate phosphate buffer at pH5) was incubated for $30 \mathrm{~min}$ at optimum temperature $35^{\circ} \mathrm{C}$. Reaction was stopped by adding $100 \mu 1 \mathrm{M}$ $\mathrm{Na}_{2} \mathrm{CO}_{3}$. Liberation of $\mathrm{p}$-nitrophenol was read using spectrophotometer at $\lambda 405 \mathrm{~nm}$. A sa blank, $100 \mu \mathrm{l}$ aquadest and $900 \mu \mathrm{l}$ substrate that were treated the same as sample condition were used and reaction was stopped by adding $100 \mu \mathrm{l}$ of $1 \mathrm{M} \mathrm{Na}_{2} \mathrm{CO}_{3}$. One unit of enzyme activity is equivalent to the amount of enzyme required to produce $1 \mu \mathrm{mol} \mathrm{p}$-nitrophenol/min [9].

$\mathrm{p}$-nitrophenol standard was made in the range of 0.1-0.5 mM p-nitrophenol from $10 \mathrm{mM} \mathrm{p}$-nitrophenol stock in phosphate citrate buffer solvent pH 5. $100 \mu \mathrm{l}$ of each standard p-nitrophenol solution was mixed with $900 \mu \mathrm{l}$ of phosphate citrate buffer $\mathrm{pH} 6$ and incubated at $35^{\circ} \mathrm{C}$ for $30 \mathrm{~min}$. Reaction was stopped by adding $100 \mu \mathrm{l}$ of $1 \mathrm{M} \mathrm{Na}_{2} \mathrm{CO}_{3}$ and absorbance was read using UV-Vis spectrophotometer at $\lambda 405 \mathrm{~nm}$.

\section{Assay of $\boldsymbol{\beta}$-glucocidase E. cloacae WPL 214 activity}

Measurement of $\beta$-glucocidase activity was assayed using $p$ NPG method. $\beta$-glucocidase activity was measured by mixing $100 \mu$ l enzyme with $900 \mu$ substrate $(1 \mathrm{mM} p$ NPG in $10 \mathrm{ml}$ of phosphate citrate buffer $\mathrm{pH} 5$ ) and incubating it at $35^{\circ} \mathrm{C}$ for $30 \mathrm{~min}$. Reaction was stopped by adding $100 \mu \mathrm{l}$ of $1 \mathrm{M}$ $\mathrm{Na}_{2} \mathrm{CO}_{3}$. As blank, $100 \mu \mathrm{l}$ aquadest and $900 \mu \mathrm{l}$ substrate that were treated the same as sample condition were used. Liberation of p-nitrophenol was read with spectrophotometer at $\lambda 405 \mathrm{~nm}$ and then compared top-nitrophenol standard curve. One unit of enzyme activity was equivalent to the amount of enzyme required to produce $1 \mu \mathrm{mol}$ p-nitrophenol/min [9].

\section{Statistical analysis}

This research was descriptive research so that the duplo data collected and analyzed in descriptive and expressed in the form of narrative and figures.

\section{Results}

\section{E. cloacae WPL 214 growth curve}

Growth curve of $E$. cloacae WPL 214 cellulolytic bacterial inoculants is shown in Figure-1. The highest growth logarithmic phase occurred at the $16^{\text {th }} \mathrm{h}$ with absorbance $(\lambda 600 \mathrm{~nm})$ of 3.122 .

\section{Optimum temperature and pH of cellulase enzyme E. cloacae WPL 214}

Incubation temperature was specified at $30^{\circ} \mathrm{C}$, $35^{\circ} \mathrm{C}, 40^{\circ} \mathrm{C}$ and $45^{\circ} \mathrm{C}$ and phosphate citrate at $\mathrm{pH} 4$, $5,6,7,8$. The highest cellulose enzyme activity was obtained at $35^{\circ} \mathrm{C}$ as much as $0.154 \mathrm{U} / \mathrm{ml}$ (Table-1) and at $\mathrm{pH} 5$ as much as $0.606 \mathrm{U} / \mathrm{ml}$ (Table-2). 


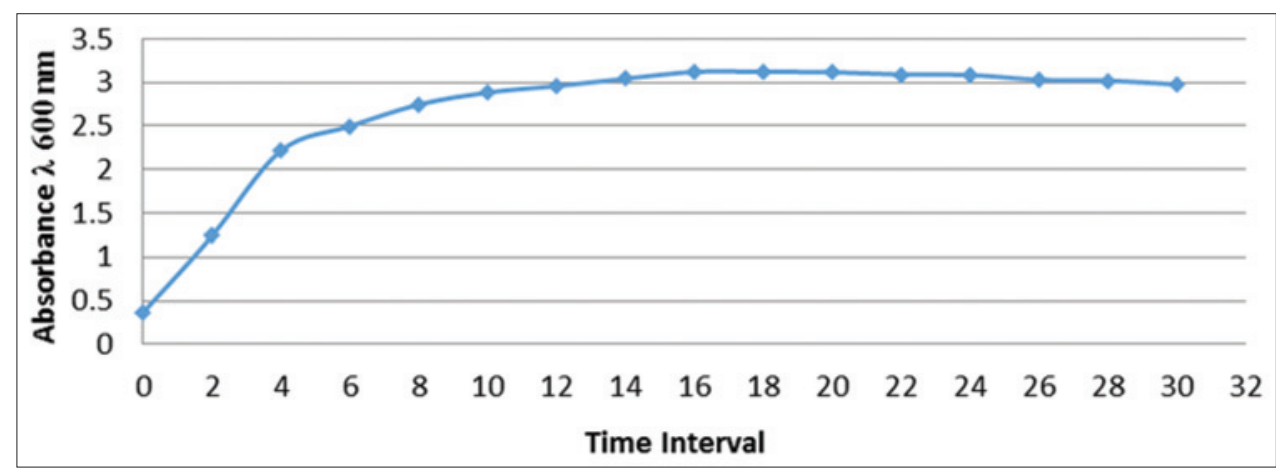

Figure-1: Growth curve of Enterobacter cloacae WPL 214 on liquid medium every $2 \mathrm{~h}$ for $30 \mathrm{~h}$

Table-1: Mean of activity of cellulase enzyme of E. cloacae WPL 214 data $(\mathrm{U} / \mathrm{ml})$ at certain temperature.

\begin{tabular}{lc}
\hline Temperature $\left({ }^{\circ} \mathbf{C}\right)$ & Activity $(\mathbf{U} / \mathbf{m L}) \pm \mathbf{S D}$ \\
\hline 30 & $0.073148 \pm 0.000327$ \\
35 & $0.154167 \pm 0.000655$ \\
40 & $0.078241 \pm 0.000982$ \\
45 & $0.037963 \pm 0.000327$ \\
\hline
\end{tabular}

E. cloacae $=$ Enterobacter cloacae, $\mathrm{SD}=$ Standard deviation

Table-2: Mean of activity of cellulase enzyme of E. cloacae WPL 214 Data $(\mathrm{U} / \mathrm{ml})$ at certain $\mathrm{pH}$.

\begin{tabular}{lr}
\hline $\mathbf{p H}$ & Activity $(\mathbf{U} / \mathbf{m L}) \pm \mathbf{S D}$ \\
\hline 4 & $0.435185 \pm 0.000655$ \\
5 & $0.606019 \pm 0.000327$ \\
6 & $0.430093 \pm 0.006547$ \\
7 & $0.321759 \pm 0.000982$ \\
8 & $0.220833 \pm 0.000655$ \\
\hline E. cloacae=Enterobacter cloacae, SD $=$ Standard deviation
\end{tabular}

Cellulase enzyme production of E. cloacae WPL 214

In addition to growth curve observation, measurement of cellulase enzyme production was also conducted. Optimum production of cellulase enzyme occurred at the end of stationary phase, at the same time as the peak of microbial growth which occured at the $22^{\text {nd }} \mathrm{h}$ (Figure-2).

\section{Discussion}

\section{E. cloacae WPL 214 growth curve}

Growth curve describes gradual growth process of a microorganism, from the beginning until the end of activity. This consists of four main phases: Lag, exponential, stationary, and death [10]. During this phase mass or cell accretion has not happened yet. Therefore, phase curve is generally flat. Lag phase interval depends on the compatibility between activity and environment setting. In this research, this phase occurs before in the first $2 \mathrm{~h}$ of $E$. cloacae WPL 214 isolate growth and followed by exponential phase.

Exponential or logarithmic phase is a phase when transformation activity increases and the accretion of microorganism growth reaches maximum speed so that the curve is in exponential form. This increasing activity should be offset by many factors among others: Biological factors, such as shape and nature of the microorganism to its environment, life association between related organism, and non-biological factors, such as temperature, $\mathrm{pH}$, and nutrient content in the growth medium. Exponential phase of E. cloacae WPL 214 isolates occurred during the first $2 \mathrm{~h}$ of incubation up to the $8^{\text {th }} \mathrm{h}$ of incubation.

Stationary phase is a phase when increased and decreased activities come to a balance. In colony growth, it means the rate of individual death equals the rate of individual birth. Therefore, this phase forms a flat curve. This phase also occurs due to diminishing nutrient sources, inhibitory compounds formation, and unfavorable environmental factors. Stationary phase of E. cloacae WPL 214 isolates occurred from the $8^{\text {th }}$ up to the $28^{\text {th }} \mathrm{h}$ of incubation with optimum growth at 16 th $\mathrm{h}$ of incubation.

Death phase is the phase when cessation of activity starts, or in colony growth, the event of death begins to exceed individual birth. Death phase of E. cloacae WPL 214 isolate soccured after $30 \mathrm{~h}$ of incubation.

\section{Cellulase enzyme production of E. cloacae WPL 214}

In addition to growth curve observation, measurement of cellulase enzyme production was also conducted. Optimum production of cellulase enzyme occurred at the end of stationary phase, at the same time as the peak of microbial growth which occurred at the $22^{\text {nd }} h$ (Figure-2). Cellulolytic activity of cellulose enzyme was assayed by performing reaction between cellulase enzyme and p-nitrophenol substrate derivatives. Exoglucanase was assayed using $p$ NPC specific substrate while cellobiase was assayed using $p$-nitrophenyl- $\beta$-D-glucopyranocide ( $p \mathrm{NPG})$ specific substrate. Enzyme activity was determined by measuring the amount of p-nitrophenol released [11]. Observations on the amount of p-nitrophenol released was observed by using spectrophotometry at $\lambda 405 \mathrm{~nm}$. One unit of cellulase enzyme activity is defined as the amount of enzyme producing $1 \mu \mathrm{mol}$ of $p$-nitrophenol in $1 \mathrm{~min}(\mathrm{U} / \mathrm{ml})$ in experimental conditions. Cellulase enzyme activity curve was used to determine the optimum time required to obtain maximum cellulase enzyme activity from enzyme production process. 


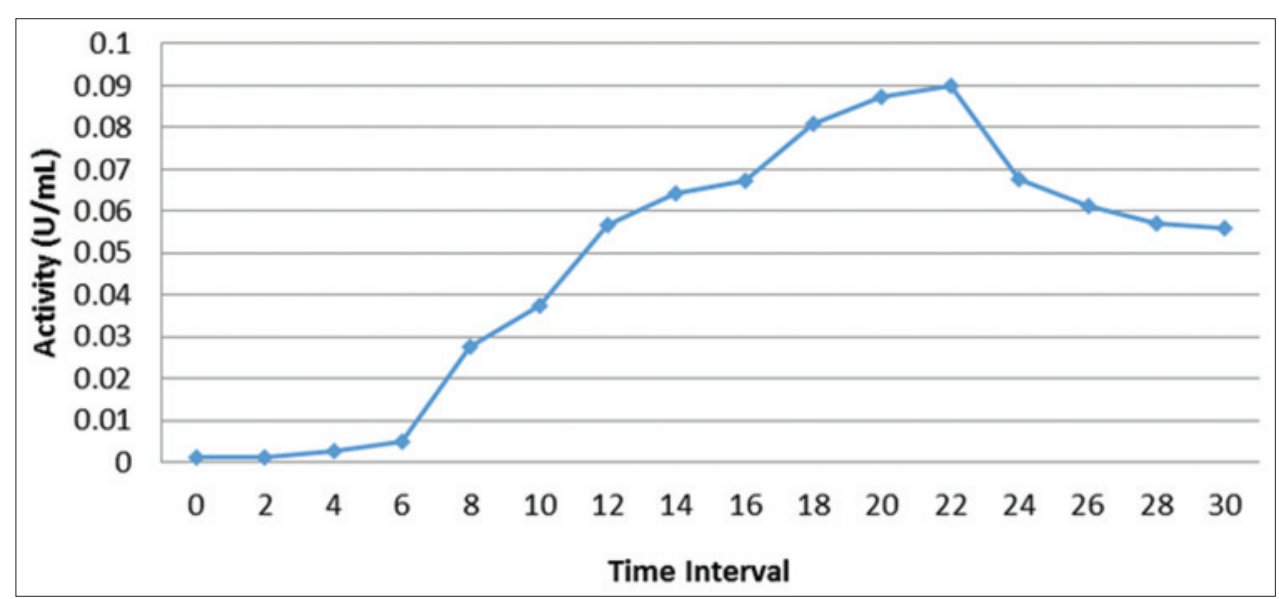

Figure-2: Growth curve of Enterobacter cloacae WPL 214 on liquid medium every $2 \mathrm{~h}$ for $30 \mathrm{~h}$

Table-3: Activity of E. cloacae WPL 214 enzyme.

\begin{tabular}{llc}
\hline Enzyme & $\begin{array}{l}\text { Specific } \\
\text { substrates }\end{array}$ & $\begin{array}{c}\text { Activity } \\
(\mathbf{U} / \mathbf{m l}) \pm \text { SD }\end{array}$ \\
\hline endo- $(1,4)-\beta-D$-glucanase & DNS & $0.09 \pm 0.00027$ \\
exo- $(1,4)-\beta-D$-glucanase & pNPC & $0.13 \pm 0.0131$ \\
$\beta$-glucocidase & pNPG & $0.10 \pm 0.0069$ \\
\hline
\end{tabular}

$\mathrm{pNPC}=\mathrm{p}-$ nitrophenyl cellobioside, $\mathrm{DNS}=3,5$-dinitrosalicylic acid, $\mathrm{pNPG}=\mathrm{p}$ - nitrophenyl $-\beta-\mathrm{D}$-glucopyranocide,

E. cloacae $=$ Enterobacter cloacae, $\mathrm{SD}=$ Standard deviation

\section{Activity of cellulolytic enzyme (endo- $(1,4)-\beta-D-g l u-$ canase, exoglucanase, and cellobiase) of $E$. cloacae WPL 214}

Measurement of exoglucanase and $\beta$-glucocidase enzyme activity was conducted using p-nitrophenol derivative substrates. Exoglucanase was assayed using $p$ NPC specific substrate while cellobiase was assayed using $p$ NPG specific substrate. Assays were carried out using the enzyme produced when enzyme activity reached optimum time, at the $22^{\text {nd }} h$. Assay was also carried out at optimum temperature of $35^{\circ} \mathrm{C}$ and optimum $\mathrm{pH}$ of 5. Data of exoglucanase and cellobiase enzyme activity are presented in Table-3. A unit of enzyme activity is defined as the amount of enzyme required to form $1 \mu \mathrm{mol}$ product per minute.

Endo- $(1,4)-\beta$-D-glucanase enzyme activity was measured simultaneously with the making of the growth curve. Sample was taken every $2 \mathrm{~h}$ and the enzyme extracted. Cellulase enzyme activity curve was used to determine the optimum time required to obtain maximum cellulase enzyme activity from enzyme production process. Figure- 2 shows data of optimum time needed to obtain optimum growth curve and optimum enzyme activity, which occurred at the $22 \mathrm{nd}$ h with enzyme activity of $0.09 \mathrm{U} / \mathrm{ml}$.

Research data of E. cloacae WPL 214 isolates showed that the optimum time to produce cellulose enzyme was at the $22^{\text {nd }} \mathrm{h}$ with endoglucanase enzyme activity of 0.09 units $/ \mathrm{ml}(\mathrm{U} / \mathrm{ml})$. Results of enzyme activity measurement using specific substrates of p-nitrophenol derivatives on E. cloacae WPL 214 isolates showed exoglucanase activity of $0.13 \mathrm{U} / \mathrm{ml}$ while cellobiose enzyme activity was at $0.10 \mathrm{U} / \mathrm{ml}$.
This result indicated that these isolates had activity on endoglucanase, exoglucanase and cellobiose enzymes. Cellulose hydrolysis requires synergistic activity of various cellulase enzymes with different specifications to produce multi enzyme system. It also requires coordination in cellulose molecule breaking, product resulted, and catalytic movement of cellulose chain $[12,13]$. Multi enzyme system of cellulose is a strategy of microorganisms to improve the effectiveness of cellulase hydrolysis, in which each enzyme has a specific function [14].

Not all Enterobacter bacteria produce cellulase enzyme. Isolation and identification have also been made from several plants, i.e. 53 endophyticentero bacteria from some plants including citrus, coconut, eucalyptus, sugarcane, and soybean. These studies identified E. cloacae, Pantoea agglomerans, Hafniaalvei, and Pantoea ananatis. The lowest cellulase enzyme production is obtained from coconut plants as much as $20 \%$ ( 2 of 10 ), equivalent to that produced by citrus crop as much as $20 \%$ (4 of 20). The level of cellulase production obtained, from the highest to the lowest, is as follows: Sugarcane, $100 \%$ (4 of 4), eucalyptus, $84.6 \%$ (11 of 13), and soybean, 83\% (5 of 6) [15]. Isolation and identification of cellulolytic bacteria from insects show the existence of cellulolytic bacteria: Enterobacter chrysanthemi, E. cloacae, and Proteus mirabilis, Erwinia chrysanthemi, among others. These microorganisms are already known to have cellulolytic activity. Cellulolytic bacteria found in the digestive tract of insects have higher cellulolytic activity ability as they are naturally involved in the digestion of lignocellulosic substrates found in insect feed. Genetic engineering (recombinant) is performed on those cellulolytic bacteria and is further used in its role of converting cellulosic biomass (CMC substrate and sugarcane bagasse) into bioethanol product more quickly and efficiently through process of fermentation at $37^{\circ} \mathrm{C}$ and $\mathrm{pH} \mathrm{7.} \mathrm{Cellulosic} \mathrm{ethanol} \mathrm{products}$ from cellulolytic bacteria aim to reduce dependence on petroleum [16].

E. cloacae isolated from pumpkin (Aulacophora atripenis) bees can grow on a medium with different 
carbon sources, including $\mathrm{CMC}$ and $2 \%$ Avicel to produce Endo-1,4- $\beta$-D-glucanase enzyme. The maximum production of cellulase enzyme is obtained after $96 \mathrm{~h}$ of fermentation. The highest endoglucanase enzyme production occurs when grown in medium of $0.75 \%$ CMC. Enzymes Endo-1,4- $\beta$-D-glucanase is optimum at $\mathrm{pH} 5.8$ and $40^{\circ} \mathrm{C}$. The maximum number of enzymes produced on CMC substrates and Avicel $2 \%$ is lower, at $0.05 \mu \mathrm{M} / \mathrm{ml}$, compared to enzyme produced on substrates of $0.75 \% \mathrm{CMC}, 0.9 \mathrm{U} / \mathrm{ml}$ [17]. E. cloacae WPL 214 isolate in this study also had 0.09 $\mathrm{U} / \mathrm{ml}$ endoglucanase enzyme activity obtained at optimum time: $22 \mathrm{nd} \mathrm{h}$ at $\mathrm{pH} 5$ and temperature $35^{\circ} \mathrm{C}$.

\section{Conclusion}

Based on the research results, it can be concluded that cellulolytic enzyme having activity ofendo- $(1,4)$ $\beta$-D-glucanase, exo-(1,4)- $\beta$-D-glucanase and $\beta$-glucosidase can be produced from cellulolytic isolates of E. cloacae WPL 214 isolated from bovine rumen fluid waste of Surabaya Abbatoir, Indonesia. This indicates that E. cloacae WPL 214 can be used to hydrolyze fibrous feeding material containing lignocellulose.

\section{Authors' Contributions}

WPL designed the research, collected and processed samples. DSN helped in designing the research. ABY carried out the data collection and gathering assay samples. TN and $\mathrm{KS}$ assisted in manuscript preparation; WPL, DSN, TN, and KS collected materials for manuscript. All authors have read and approved the final manuscript.

\section{Acknowledgements}

The authors would like to thank the Directorate of Research and Community Services of Directorate General of Higher Education, Ministry of Education and Culture and Rector of Airlangga University that have funded Decentralization research, university leading research (PUPT) according to Rector Decree No. 1349/UN3/2014 dated May 9 ${ }^{\text {th }}, 2014$.

\section{Competing Interests}

The authors declare that they have no conflict and competing interests.

\section{References}

1. Kamra D.N. (2005) Rumen microbial ecosystem. Special section: Microbial diversity Curr. Sci., 89(1): 122-243.

2. Ekinci, M.S, Martin, J.C. and Flint, H.J. (2002) Expression of a cellulase gene, ce1A, from the rumen fungus Neocallimastix patriciarum in Streptococcus bovis by means of promoter fusions. J Biotechnol. Lett., 24: 735741. In Sajjad, M, Andrabi, S.M.H, Akhter, S. and Afzal M. (2008). Application of biotechnology to improve post-ingestion forage quality in the rumen. Pak. J. Nutr., 7(1): 70-74.

3. Mathew, G.M., Sukumaran, R.K., Singhania, R.R. and Pandey, A. (2008) Progress in research on fungal cellulases for lignocellulose degradation. J. Sci. Ind. Res., 67: 898-908.

4. Howard, R.L., Abotsi, E., van Rensburg, E.L.J. and Howard, S. (2003) Lignocellulose biotechnology: Issues of bioconversion and enzyme production. Afr. J. Biotechnol., 2(12): 602-619.

5. Lynd, L.R., Weimer, P.J. and Pretorius, I.S. (2002) Microbial cellulose utilization: Fundamentals and biotechnology. Microbiol. Mol. Biol. Rev., 66(3): 506-577.

6. Perez, J., Munoz-Dorado, J., de la Rubia, T. and Martinez, J. (2002) Biodegradation and biological treatments of cellulose, hemicellulose and lignin: an overview. Int Microbiol., 5: 53-63.

7. Puspaningsih, N.Y.T. (2004) Biochemistry I, Universitas Airlangga, Surabaya.

8. Ahmed, I., Zia, M.A. and Iqbal, H.M.N. (2010) Bioprocessing of proximally analyzed wheat straw for enhanced cellulase production through process optimization with Trichoderma viridae under SSF. Int. J. Biol. Life Sci., 6: 3 .

9. Han, S.J., Yoo, Y.J. and Kang, H.S. (1995) Characterization of a bifunctional cellulase and its structural gene. The cell gene of Bacillus sp. D04 has exo- and endoglucanase activity. J. Biol. Chem., 270(43): 26012-26019.

10. Purnomo, B, (2004) Growth and Metabolism Organism. The Basic of Microbiology, Indonesia.

11. Lymar, E.S., Li, B. and Renganathan, V. (1995) Purification and characterization of a cellulose-binding $\beta$-glucosidase from cellulose-degrading cultures of phanerochaete chrysosporium. Appl. Environ. Microbiol., 61(8): 2976-2980.

12. Li, Y., Irwin, D.C. and Wilson, D.B. (2010) Increased crystalline cellulose activity via combinations of amino acid changes in the family 9 catalytic domain and family $3 \mathrm{c}$ cellulose binding module of Thermobifida fusca Ce19A. Appl. Environ. Microbiol., 76(8): 2582-2588.

13. Irwin, D.C., Zhang, S. and Wilson, D.B. (2001) Cloning expression and characterization of a family 48 exocellulase, cel48a, from Thermobifida fusca. Eur. J. Biochem., 267: 4988-4997.

14. Beg, Q.K.M., Kapoor, L., Mahajan, G. and Hoondal, S. (2001) Microbial xylanase from the newly isolated Bacillus sp. Strain BP-23. Can. J. Microbiol., 39: 1162-1166.

15. Torres, A.R., Araujo, W.L., Cursino, L., Hungria, M., Plotegher, F., Mostasso, F.L. and Azevedo, J.L. (2008) Diversity of endophytic enterobacteria associated with different host plants. J. Microbiol., 46(4): 373-379.

16. Piriya, P.S., Vasan, P.T., Padma, V.S., Vidhyadevi, U., Archana, K. and John Vennison, S. (2012) Cellulosic ethanol production by recombinant cellulolytic bacteria harbouring pdc and adh II genes of Zymomonas mobilis. Biotechnol. Res. Int., 2012: 817549.

17. Sami, A.J., Awais, M. and Shakoori, A.R. (2008) Preliminary studies on the production of endo-1,4-b-dglucanases activity produced by Enterobacter cloacae. Afr. J. Biotechnol., 7(9): 1318-1322. 